\title{
PENTINGNYA STANDAR ISSU TERKAIT BUDAYA KESELAMATAN PASIEN DI RUMAH SAKIT
}

\author{
EBIAL FITRI BR GINTING \\ ebyalfitriginting@gmail.com
}

\section{Latar Belakang}

Keselamatan telah menjadi isu global termasuk juga untuk rumah sakit. Penerapan budaya keselamatan pasien dalam sebuah organisasi tidak terlepas dari peran aktif atasan (supervisor atau manajemen dalam mempromosikan dan melakukan tindakan-tindakan yang mendukung berjalannya proses penanaman nilai yang dianut. Perlu ada perubahan budaya didalam rumah sakit agar budaya keselamatan pasien semakin baik. Budaya keselamatan yang baik dapat mengurangi resiko terjadinya kejadian yang tidak diinginkan. Maka, diperlukan pelatihan secara rutin bagi petugas medis agar benar-benar memahami budaya keselamatan pasien. pengawasan dari atasan juga harus ditingkatkan sebagai salah satu upaya untuk menerapkan budaya keselamatan pasien. Jika itu semua dilakukan maka budaya keselamatan pasien akan berjalan dengan baik. Terkait dengan upaya upaya keselamatan pasien untuk menekan angka kejadian tidak diinginkan di rumah sakit, diyakini bahwa upaya menciptakan atau membangun budaya keselamatan (safety culture) merupakan langkah pertama dalam langkah-langkah mencapai keselamatan pasien. inti dari budaya keselamatan pasien adalah keyakinan tenaga medis tentang pentingnya keselamatan, yang ditunjukkan melalui sikap, norma-norma yang berlaku dan perilaku termasuk nilai-nilai yang menjadi asumsi dasar tentang bagaimana bertindak.

Isu keselamatan pasien atau patient safety merupakan salah satu isu yang dibahas dalam pelayanan kesehatan. Menurut World Health Organization (WHO) pada tahun 2004 mengumpulkan angka-angka penelitian dari setiap Negara seperti Amerika, Denmark, Inggris, dan Australia di temukan bahwa angka KTD (Kejadian Tidak Diharapkan) dengan rentang 3,2 - 16,6\%. Data di Indonesia tentang KTD masih langka, 
namun dilain pihak banyak terjadinya

peningkatan tuduhan "Mal Praktek", yang belum tentu sesuai dengan pembuktiannya (DepKes, 2006).

Keselamatan pasien (patient safety) merupakan isu global dan nasional bagi rumah sakit, komponen penting dari mutu layanan kesehatan, prinsip dasar dari pelayanan pasien dan komponen kritis dari manajemen mutu. Dalam lingkup nasional, sejak bulan Agustus 2005, Menteri Kesehatan RI telah mencanangkan Gerakan Nasional Keselamatan Pasien (GNKP) Rumah Sakit, selanjutnya Komite Akreditasi Rumah Sakit (KARS) Depkes RI telah pula menyusun Standar Keselamatan Pasien Rumah Sakit (KP RS) yang dimasukkan ke dalam instrument akreditasi RS di Indonesia (KKP-RS, 2006).

Metode

Metode yang digunakan adalah metode kualitatif dimana maksudnya dengan cara mengumpulkan sebanyak-banyaknya data untuk dianalisis. Yaitu dengan Literature review ini dengan menganalisis yang berfokus pada pentingnya standar issu terkait budaya keselamata pasien di rumah sakit. Adapun tinjauan literatur yang digunakan seperti buku teks, buku referensi, jurnal, dan google scholar. Dengan kata kunci standar,issu, dan budaya keselamatan pasien. Dan yang digunakan adalah 10 literatur yang diterbitkan 10 tahun terakhir.

Hasil

Budaya keselamatan pasien adalah pola terpadu perilaku individu dan organisasi dalam memberikan pelayanan yang aman dan bebas dari cedera. Secara garis besar yang dikatakan dengan budaya keselamatan pasien adalah keyakinan, persepsi, perilaku dan kompetensi individu atau kelompok dalam suatu organisasi yang mempunyai komitmen untuk bersama-sama menciptakan lingkungan yang aman. menciptakan budaya pelayanan kesehatan yang aman maka adanya tanggung jawab dari setiap petugas kesehatan untuk menanamkan nilai-nilai budaya keselamatan pasien di seluruh rumah sakit. Nilai tersebut dapat berupa kedisiplinan, kepatuhan terhadap standar 
prosedur, dan protokol yang ada, tim work, adanya nilai kejujuran dan keterbukaan serta rasa saling menghormati.

Isu keselamatan pasien atau patient safety merupakan salah satu isu yang dibahas dalam pelayanan kesehatan. Menurut World Health Organization (WHO) pada tahun 2004 mengumpulkan angka-angka penelitian dari setiap Negara seperti Amerika, Denmark, Inggris, dan Australia di temukan bahwa angka KTD (Kejadian Tidak Diharapkan) dengan rentang 3,2 - 16,6\%. Data di Indonesia tentang KTD masih langka, namun dilain pihak banyak terjadinya peningkatan tuduhan "Mal Praktek", yang belum tentu sesuai dengan pembuktiannya (DepKes, 2006).

\section{Pembahasan}

Keselamatan pasien merupakan isu global dan komponen penting dari mutu layanan kesehatan, prinsip dasar dari pelayanan pasien dan komponen kritis dari manajemen mutu. Di Indonesia, program keselamatan pasien dirancang pada tahun 2005 dan terus berkembang menjadi isu utama dalam pelayanan medis di Indonesia. dalam hal menganalisis budaya keselamatan pasien dapat dilihat dari pengukuran indikator pola komunikasi, sistem pelaporan insiden (organisasi pembelajar), kerjasama tim, pendidikan dan pelatihan, iklim kerja, komitmen pimpinan, dan no blaming kultur.

Adanya pengaruh kerja tim dengan maturitas budaya keselamatan pasien, adanya komitmen yakni staf berkomitmen mendukung meningkatkan program keselamatan pasien. Adanya komunikasi ide dan gagasan yakni pimpinan selalu ikut berkontribusi terhadap peningkatan program pasien safety. Parikesit termasuk dalam kategori yang baik dan berada pada tingkat maturitas budaya keselamatan pasien yang proaktif. maturitas budaya keselamatan berada pada tingkat proaktif tetapi masih terdapat indikator-indikator yang belum optimal. Banyak kesalahan pelayanan dikaitkan dengan budaya patient safety. Banyak kesalahan medis dikaitkan dengan budaya patientsafety. Sebagai organisasi pelayanan kesehatan yang secara kontinyu memperbaiki pelayanannya, penting bagi rumah sakit untuk menumbuhkan budaya sefety (culture of safety). Untuk mencapai budaya sefety dibutuhkan pemahaman tentang nilai, kepercayaan, norma penting dalam organisasi, dan dan sikap serta 
perilaku yang terkait patient safety.

Data yang dirilis oleh Health and Human Service (HHS) menunjukkan bahwa sepanjang 2010-2014 di Amerika telah terjadi penurunan kejadian terkait patient safety di RS sebesar $17 \%$. Hal ini telah memberi kontribusi utama terhadap menurunnya kematian pasien (akibat kejadian tidak diinginkan) sebanyak 87 ribu kasus. Ini merupakan langkah yang baik menuju zero patient harm bagi pelayanan kesehatan di Amerika.

1. Medical errors

2. Diagnostic errors

3. Merumahkan pasien (home-care) pasca akut

4. Keselamatan di tempat kerja

5. Keselamatan di fasilitas RS

6. Pemrosesan ulang

7. Sepsis

8. Bakteri

9. Ketidakamanan maya perangkat medis.

10. Transparansi data medis

Budaya keselamatan pasien yang diharapkan di rumah sakit adalah budaya keselamatan positif yang ditandai dengan adanya alur informasi yang baik, memiliki pemimpin yang komit dan eksekutif yang bertanggung jawab serta pendekatan untuk tidak menyalahkan dan tidak memberikan hukuman pada insiden yang dilaporkan. budaya keselamatan pasien dikatakan berhasil apabila semua elemen yang ada di dalam rumah sakit menerapkan budaya keselamatan pasien dalam pekerjaannya sehari -hari.

Manajemen patient safety memegang peranan sangat penting dalam 
peningkatan mutu pelayanan kesehatan. Patient safety merupakan suatu variabel untuk mengukur dan menilai kualitas pelayanan suatu asuhan yang berdampak terhadap pelayanan kesehatan. Kejadian Tidak Diharapkan atau KTD sering terjadi pada pasien saat mendapatkan perawatan di rumah sakit, sehingga kejadian tersebut sangat merugikan bagi pasien tersebut juga bagi rumah sakit sendiri. KTD bisa terjadi karena berbagai faktor diantaranya beban kerja perawat yang berat, komunikasi yang kurang tepat, penggunaan alat dan sarana yang kurang tepat bisa memicu terjadinya patient safety (Nursalam, 2011).

Penilaian terhadap budaya keselamatan pasien merupakan permulaan dari proses pengembangan program keselamatan pasien itu sendiri yang hasilnya dapat digunakan untuk mengidentifikasi area/unit yang akan dikembangkan, untuk evaluasi program, untuk membuat perbandingan secara internal maupun eksternal dan sebagai dasar pembuatan kebijakan. Keselamatan pasien merupakan isu global yang paling penting saat ini, di mana sekarang banyak dilaporkan tuntutan pasien atas medical error yang terjadi pada pasien. Keselamatan pasien rumah sakit adalah suatu sistem dimana rumah sakit membuat asuhan pasien lebih aman yang memiliki asesmen risiko, identifikasi dan pengelolaan hal yang berhubungan dengan risiko pasien, pelaporan dan analisis insiden, kemampuan belajar dari insiden dan tindak lanjut. sejak malpraktik menggema di seluruh belahan bumi melalui berbagai media baik cetak maupun elektronik hingga ke jurnal-jurnal ternama, dunia cassetta mulai menaruh kepedulian yang tinggi terhadap isu keselamatan pasien. Berbagai Hasil studi merekomendasikan untuk memperbaiki upaya keselamatan pasien dengan memperhatikan isu-isu budaya/iklim keselamatan pasien di langkah awal. Menurut agency of healthcare research and quality dalam menilai budaya keselamatan pasien di rumah sakit terdapat beberapa aspek dimensi yang perlu diperhatikan, yaitu harapan dan tindakan supervisor/manajer dalam mempromosikan keselamatan pasien, pembelajaran peningkatan berkelanjutan, kerjasama tim dalam unit, keterbukaan komunikasi, umpan balik terhadap error, respon tidak menyalahkan, staf yang adekuat, persepsi secara keseluruhan, dukungan manajemen rumah sakit, kerjasama tim antar unit, penyerahan dan pemindahan pasien dan frekuensi pelaporan kejadian. 
Keselamatan pasien di rumah sakit adalah suatu sistem dimana rumah sakit membuat asuhan pasien lebih aman. Sistem tersebut meliputi: asesmen risiko, identifikasi dan pengelolaan hal yang berhubungan dengan risiko pasien, pelaporan dan analisis insiden, kemampuan belajar dari insiden dan tindak lanjutan Nya serta implementasi solusi untuk meminimalkan timbulnya risiko. sistem tersebut diharapkan dapat mencegah terjadinya cedera yang disebabkan oleh kesalahan akibat melaksanakan suatu tindakan atau tidak melakukan tindakan yang seharusnya dilakukan.

Rumah sakit dapat melakukan tujuh upaya khusus untuk menjaga keselamatan pasien, seperti membangun kesadaran akan nilai keselamatan pasien, memberi arahan dan dukungan pada tenaga kesehatan, mengintegrasikan aktivitas resiko, mengembangkan sistem pelaporan, selalu melibatkan dan berkomunikasi dengan pasien, belajar dan berbagi pengalaman tenaga kesehatan pasien, mencegah cedera melalui implementasi sistem keselamatan pasien. Mutu pelayanan di rumah sakit juga dipengaruhi oleh mutu pelayanan keperawatan karena pelayanan keperwatan merupakan bagian integral dari pelayanan kesehatan (DepKes, 2006).

\section{Penutup}

Budaya keselamatan pasien yang diharapkan di rumah sakit adalah budaya keselamatan positif yang ditandai dengan adanya alur informasi yang baik, memiliki pemimpin yang komit dan eksekutif yang bertanggung jawab serta pendekatan untuk tidak menyalahkan dan tidak memberikan hukuman pada insiden yang dilaporkan. budaya keselamatan pasien dikatakan berhasil apabila semua elemen yang ada di dalam rumah sakit menerapkan budaya keselamatan pasien dalam pekerjaannya sehari -hari. Keselamatan pasien merupakan isu global dan komponen penting dari mutu layanan kesehatan, prinsip dasar dari pelayanan pasien dan komponen kritis dari manajemen mutu. Di Indonesia, program keselamatan pasien dirancang pada tahun 2005 dan terus berkembang menjadi isu utama dalam pelayanan medis di Indonesia. dalam hal menganalisis budaya keselamatan pasien dapat dilihat dari pengukuran indikator pola komunikasi, sistem pelaporan insiden (organisasi pembelajar), kerjasama tim, pendidikan dan pelatihan, iklim kerja, komitmen pimpinan, dan no blaming kultur. 


\section{Daftar Pustaka}

Najihah. 2018. Budaya Keselamatan Pasien dan Insiden Keselamatan Pasien di Rumah Sakit. Literature Review Journal of Islamic Nursing. Vol 3(1). 1-8.

Juniarti, N., H. \& Mudayana, A., A. (2018). Penerapan Standar Keselamatan Pasien Di Rumah Sakit Umum Daerah Provinsi Nusa Tenggara Barat. Jurnal Kesehatan Poltekkes Ternate. 11(2), 93-108.

Sumarni. (2017). Analisis Implementasi Patient Safety Terkait Peningkatan Mutu Pelayanan Kesehatan di Rumah Sakit. Jurnal Ners dan Kebidanan Indonesia.5(2), 91-99.

Rahmayunia, Imelda Kartika dan Yelpio Stenalia. 2016. Deskripsi Penerapan Patient Safety pada pasien di Bangsal Bedah. Jurnal Human Care. Vol 4(2). 86-94.

Tri, Yennike Herawati. 2015. Budaya Keselamatan Pasien di ruang rawat inap Rumah Sakit X Kabupaten Jember. Jurnal IKESMA. Vol 11(1). 52-60.

Vellyana, Diny dan Asri Rahmawati. 2016. Blaming Culture dan Sanksi Kesalahan dalam Budaya Keselamatan Pasien. Jurnal IImiah Kesehatan. Vol 5(9). 1-14.

Yusuf, M. (2017). Penerapan Patient Safety Di Ruang Rawat Inap Rumah Sakit Umum Daerah Dr. Zainoel Abidin. Jurnal Ilmu Keperawatan. 5(1), 84-89.

Kamil, H. ( 2010). Patient Safety. Idea Nursing Journal. 1(1), 1-8.

Ahid, Ahmad Mudayana. 2014. Peran Aspek Etika Tenaga Medis dalam Penerapan Budaya Keselamatan pasien di Rumah Sakit. Supplemen Majalah Kedokteran Andalas. Vol 37(1). 69-74.

Simamora, R. H., \& Nurmaini, C. T. S. (2019). Knowledge of Nurses about Prevention of Patient Fall Risk in Inpatient Room of Private Hospital in Medan. Indian Journal of Public Health Research \& Development, 10(10), 759-763.

Silalahi, Maurits, Fridawaty Rivai, Ridwan Amiruddin. 2018. Pengaruh faktor organisasi terhadap maturitas budaya keselamatan pasien di rumah sakit A. M Parikesit Tanggerang Tahun 2017. JKMM. Vol (1)1. 22-30. 
V7 Edit dengan WPS Office 